\title{
DO THE SELECTED CHARACTERISTICS OF PUBLIC TENDERS AFFECT THE LIKELIHOOD OF FILING PETITIONS WITH THE REGULATORS OF PUBLIC TENDERS?
}

\author{
Michal Plaček, Martin Schmidt, František Ochrana, Michal Půček*
}

\begin{abstract}
The article deals with the econometric analysis on the influence of selected characteristics of public contracts with respect to the decision making of bidders on public contracts regarding submissions to initiate proceedings to review the actions of the contracting authority at the Office for Protection of Competition. Logistic regression was applied to data on public procurement between the years 2007 and 2014, which was combined with the administrative decisions of the Office for the Protection of Competition, in order to identify the factors that affect the likelihood that the competitors will be protected against the conduct of the contracting authority by the Office for the Protection of Competition. The article also takes into account the possible obstructive behaviour of candidates, particularly those submissions which were subsequently withdrawn or submissions whose deposits were not paid.
\end{abstract}

Keywords: public procurement, size of the public contract, the choice of evaluation criteria, the transparency of the public tender

JEL Classification: H57, H72, H77

\section{Introduction}

A significant volume of resources are given out annually on pubic contracts. In the EU this volume amounts, on average, to about 14\% of GDP (EC, 2014). In the Czech Republic (see www.vestnikverejnychzakazek.cz), the size of the public procurement market in 2013 was around CZK 493 billion. Approximately 60\% of the funds of these resources were allocated through the direct scope of the relevant Act. The remaining $40 \%$ were small-scale public contracts, which are not covered by the statutory duty which requires the publishing of the tender, or when there were exceptions to the tender which were established by the law on public procurement. A similar state of affairs was seen in 2014. According to estimates, in 2014 there was an increase in the volume of the public procurement market to CZK 577 billion. From this total, $78 \%$ of the cash resources were allocated through the Act on Public Contracts. Public procurement is therefore an important instrument of fiscal policy.

In economic theory, public procurement is dominated by two concepts, namely the competitive effect and the effect of capacity (Domberger, Rimmer, 1994; Milne,

* Michal Plaček, Center for Social and Economics Strategies, Prague, Czech Republic (michalplacek@seznam.cz);

Martin Schmidt, Center for Social and Economics Strategies, Prague, Czech Republic (m.schmidt@email.cz);

František Ochrana, Center for Social and Economics Strategies, Prague, Czech Republic (frantisek.ochrana@fsv.cuni.cz);

Michal Půček, Center for Social and Economics Strategies, Prague, Czech Republic

(milan.pucek@seznam.cz). 
McGee, 1992). The competitive effect is related to the openness of the tender, as detailed in the case of EU countries, e.g. shown in a study of the European Commission (Strand, Ramada, Canton, et al., 2011). Both effects have been studied as interacting (Burget, Che, 2004), but also with other accompanying phenomena, such as the example of the overpricing of public contracts for construction (Pavel, 2010), or in connection with the analysis of the impact of the evaluation criteria on the price of public contracts and the relationship between corruption and openness of the procurement procedure (Ochrana, Maaytová, 2012). There is also a relatively detailed study of the impact of outsourcing on the effectiveness of the procurement of goods and services (Měřičková, Nemec, 2007), (Mikušová - Měřičková, Nemec, 2013), (Svidroňová, Vaceková, 2012), (Horńáková, Špaček, 2013), the influence of the amount of submissions on the final price of a public contract (Iimi, 2006) and the phenomenon of accumulation of submissions in the vicinity of the price limits of the submissions (Nikolovová et al., 2012). The studies consensually agree that it is the factor of competitive effects and the transparency factor (Pavel, Sičáková-Beblavá, 2008), which have a demonstrable impact on efficiency (regarding the final price of tenders). Another area of investigation is the analysis of the regulatory framework for public procurement (Jurčík, 2007, 2012) and international comparison of public contracts (Nemec et. al., 2014).

We found only two studies regarding the problem of post-contractual behaviour in the research literature. The first study (Pavel, Sičáková-Beblavá, 2012), which is on the example post-contractual behaviour of contracting authorities in the Slovak Republic, focuses on the problem which can occur during the execution of a public contract when there are changes in the internal and external conditions that require adjustments to the contract. The aforementioned study covers the time period 2005-2009. Pavel and Sičáková-Beblavá examined the changes via amendments to contracts from 19 municipalities in the case of 234 observations (local level of government), and 153 observations in the case of central government authorities. They conclude that both types of authorities made amendments and in an almost identical (one-quarter) proportion of cases. They noted that the changes did not always have an impact on price, but that they also reflected changes in dates, or even changes in the address of the supplier. The study by Pavel, Sičáková-Beblavá (2012) clearly addresses the problem of what are the economic motives for making amendments to contracts, but does not examine factors that influence the lodging complaints by tenderers with the public contract regulators (Office for the Protection of Competition). The second study (Schmidt, 2014) focuses directly on the part of the activities carried out by the Office for the Protection of Competition, and on the penalties awarded by the authority for committing an administrative offense by the contracting authority during the procurement procedure.

With regard to the determined state, our study deals with the unresolved issues in the scientific literature, and on an analysis of the impact of selected factors that influence the decision making of the tenderers to initiate proceedings with the regulators of the public contract. A significant difference of our study when compared with these studies (Paul Sičáková-Beblavá, 2012; Schmidt, 2014) also lays in the fact that we start from the analysis of a significantly richer set of public contracts and decisions from the Office for the Protection of Competition. 


\section{Theoretical Framework and Background Investigation - Hypotheses}

In our study, we will deal with the case of external production in the form of public procurement. This method of supporting public good and services also has implications on transaction costs (Coase, 1937; Bajari, Tadelis, 2001), when the subject of the analysis of the economics of the transaction costs is the regulatory set up of relations between the different economic actors (Hart, Shleifer, Vishny, 1997). From the perspective of new institutional economics, internal production is based on command relationships (employment contract), whereas external production is carried out on the contractually defined shift. Neither type of policies is perfect. They both exhibit imperfections. A different interpretation of contracts from the side of the economic actors concerned carries the risk of an additional increase in transaction costs (Potoski, Brown, 2003). The amount of transaction costs and the probability of their occurrence depends on many factors (Williamson, 1981). From these, we consider the following to be crucial in our study: the quality of regulatory standards that are defined by the Act on Public Contracts, the phenomenon of opportunistic behaviour (Williamson, 1971) regarding some of the tenderers and the role of the regulator (the Office for Protection of Competition) overseeing the observance of the rules of competition and responding to submissions of tenderers (Nemec et al., 2015).

In the Czech Republic, the rules for public tender are defined by Act on Public Contracts (Act No. 137/2006 on Public Contracts, as amended). A significant change in the law in recent years has been amendment No. 55/2012 Coll. Known as the Transparent Amendment which lowers the financial limits for publication of public contracts the contracting bodies are obliged to follow pursuant to the Act (from CZK 6 million to CZK 3 million regarding construction contracts and from CZK 2 million to CZK 1 million for contracts for goods and services). At the same time, certain problematic legal statutes such as a limit on the number of candidates by lot or the possibility to set qualification requirements for financial indicators were also eliminated. In addition, it introduced certain new obligations for the contracting bodies resulting in the publication of tender documents and procurement contracts on individual profiles of the contracting bodies, as well as the subsequent price actually paid as well as the list of subcontractors who were involved in the contract. These changes to the law, as in the institutional framework of public procurement, thus affect the behaviour of contracting bodies and tenders and thus the volume of the submitted objections and submissions to the Office for Protection of Competition, as shown in Figure 1.

In the case of this article, we focus on the analysis of the situation where an economic agent seeking to acquire a public contract does not agree with the procedures of the contracting body, which it considers to be illegal and therefore they have filed an objection against it. The reasons for this may be, for example, a disputed disqualification from the tenderer, the decision regarding the selection of the best submission, the cancelation of the award procedure or that the actual tender specifications do not allow some suppliers access to the procurement procedure. In the event that the given contracting body decides not to comply with the objections, the responsible supplier can accept the decision, or if they disagree and believe that the contracting body violated the Act on Public Contracts, the tenderer may initiate proceedings to review the actions of the contracting body. 


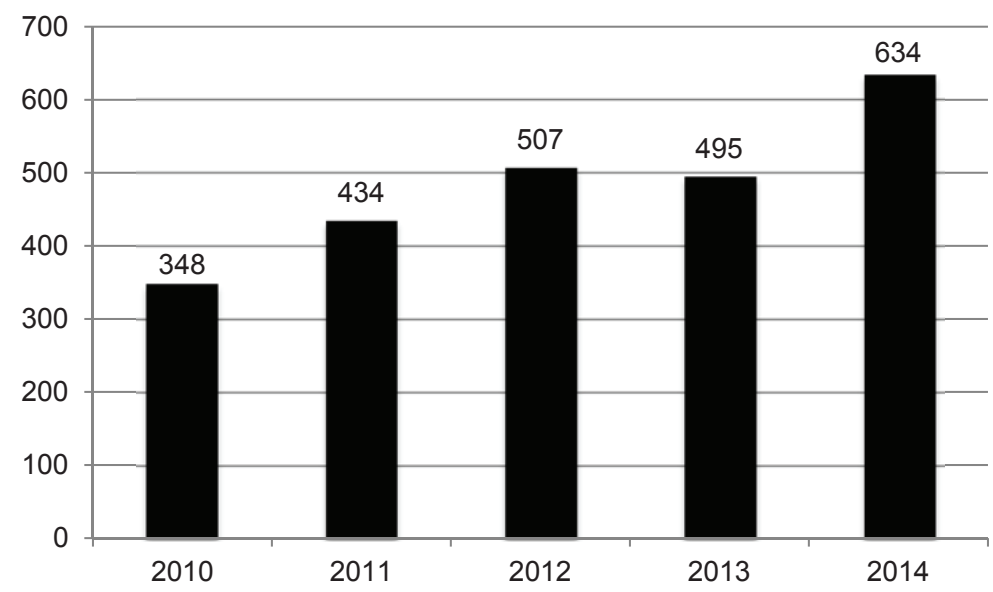

Source: Office for Protection of Competition

The proposal to initiate proceedings for a review of actions is submitted to the Office for Protection of Competition. The particulars of the proposal are provided by $\S 114$ of Act on Public Contracts, and a deposit of $1 \%$ of the bid price (a minimum of CZK 50,000) is required to make the application. The deposit is forfeited to the state budget if the proposal is rejected in substance. An application to the Office for Protection of Competition may lay outside the interest in obtaining a public contract, and be opportunistic or motivated by goals to create obstructions affecting the implementation of the public contract.

From the view of the behaviour of the objecting candidates, we identified two types of tenderers and their respective strategies. The first type are the "honest candidates" who are appealing because they are convinced that the rules of the tender were not complied with. They utilize the regulations provided by the Act on Public Contracts in good faith so that when filing an objection to the competition regulator they do so in order to remedy an injustice. The second type of objecting candidates behave opportunistically. They make use of the Act on Public Contracts regarding unfair practices (deceit, fraud). They seek to utilize ("exploit") it so as to maximize their own benefit.

In this study, we start from the simplifying the assumption that we are looking at both kinds of players as rationally behaving economic agents who pursue a goal of maximizing expected utility. We were inspired by the theories of rational choices based on maximizing the benefits. Economic agents make decisions in a way that follows the size of the expected profit, which also depends on the size of the benefit of each option and to the probability to which the success of the option is linked (Neumann and Morgenstern, 1944). In relation to the problem of objecting tenderers, this means that both objecting candidates behave in such a way as to take into account the expected benefits and the likelihood that they will succeed in the petition in their decision-making process (whether to submit a proposal to the competition regulator). Formally, it is possible to express the conduct of competitors who sent appeals to the Office for Protection of Competition as follows; written as the following formula: 


$$
U_{\text {submission }}=\text { prob }_{\text {granted petition }} \times \text { prob }_{\text {acquirement of a public contract }} \mathrm{x}
$$

expected profit from a public contract + prob $b_{\text {rejected petition }}(-$ guarantee $)+p_{\text {cessation of proceedings }} \mathrm{X}$

$$
0 \text { - transaction cost of a submission }
$$

Table 1 | Decisions Issued by Office for Protection of Competition Regarding Petitions from January-August 2015

\begin{tabular}{|l|c|c|}
\hline Decision & Amount & $\%$ \\
\hline Rejected petitions & 62 & 22.3 \\
\hline Granted petitions & 55 & 19.8 \\
\hline Cessation due to withdrawal of the petition & 43 & 15.4 \\
\hline $\begin{array}{l}\text { Cessation due to failure of providing the deposit or other formal } \\
\text { errors }\end{array}$ & 48 & 17.3 \\
\hline $\begin{array}{l}\text { The contracting body itself annulled the contested action or } \\
\text { the entire tender procedure }\end{array}$ & 37 & 13.3 \\
\hline $\begin{array}{l}\text { Cessation due to the contracting authority concluding } \\
\text { the contract }\end{array}$ & 18 & 6.5 \\
\hline Other reasons which ceased the proceedings & 15 & 5.4 \\
\hline
\end{tabular}

Source: Office for Protection of Competition Reports, own calculations

The said calculation of benefits (for a risk-neutral case), expressed as the expected monetized proceeds from the submission includes basic options regarding how the submission can be decided. First, the proposal can be accepted, and the Office for Protection of Competition will decide to impose corrective measures (equivalent in terms of suppliers, such as the cancelation of the action directly by the contracting body), or it may be dismissed and the petitioners in this case will have to forfeit the deposit, or it may stop proceedings on other procedural grounds. The corresponding probabilities can be estimated from the decision of the Office in the past (see Table 1). Transaction costs (excluding the deposit), e.g. costs of legal representation, are also related to the filing of the submission. The Supplier therefore compares the expected benefits associated with filing a motion with the zero option which consists of withholding the submission. In the case of obstructive negotiations the supplier probably does not calculate (i.e. does not necessarily calculate) the gain from direct execution of the public contract, but his motivation may lie, for example, in the failure to allow the engagement of the competition. During the so-called obstructive filings, it can also be assumed that the candidate who sends submissions to the Office for Protection of Competition is pursuing a long-term goal. In game theory this situation is described as a game with endless repetitions, where the optimum strategy is "do unto you as you do unto me". Therefore the tenderer gives a clear signal to the contracting body that, in the case of other contracts listed with him, the contracting body must take into account and that it would require "equal treatment". In our study we do not aim to find out 
what the motives for "obstructive behaviour" of this type of tenderers are. This problem is rather psychological and sociological. We are focussing on the analysis of selected factors (the size of the public contract, evaluation criteria, the transparency of tendering and the type of contracting body), which we consider to have an impact on the decisionmaking of the tenderers of the public tender when submitting the petition (complaint) to the regulators of the public competition. The competition regulator discusses these petitions and issues decisions on them. An example of a decision from our study has undergone a detailed analysis in our study is given in the following table (Table 1)

In our analysis, we will focus further attention on factors describing specific public contracts, which can also be viewed from view of the tenderer as to influence the decision on the filing of a petition to the Office for Protection of Competition. We will therefore analyse whether certain types of procurement are susceptible to the filing of petitions. Relevant factors may be:

- The size of the contract - it can be assumed that contracts with larger volumes are more attractive to suppliers because the larger sized contract are associated with a higher expected profit. Even with the lower level of probability of success, a relatively large benefit can be expected. We measure the size of orders by the indicator of the estimated value public contracts.

- Evaluation criteria - the contracting bodies can choose either an evaluation based solely on the lowest bid price, or by economically advantageous tender. This case concerns a comprehensive evaluation criterion, which has partial evaluation criteria, with tender prices among the other sub-criteria, for example, indicators of performance, delivery time, operating costs, and aesthetic properties. When selecting a complex evaluation criteria, sub-criteria must be established, and on the basis of an assessment the bids are made. The contracting bodies more often choose the price as a criterion, because it is easier to use and eliminates the risk of potential complications associated with multi-criteria evaluation.

- The openness of the selection process (i.e. the type of procurement procedure) the more open selection process is, the more players who can participate in the contest there will be, while in the case of a closed tender (negotiated procedure without publication), the contracting body must somehow justify this form.

- Type of contracting authority - we expect that with the higher the degree of decentralization of public procurement, there will be greater the pressure for accountability of the contracting body, for example. Municipalities, to a certain extent, are under greater public scrutiny than the central authorities.

The aim of this article is therefore based on an econometric model to analyse the characteristics of selected public contracts and their impact on the likelihoods that the tenderer will file a petition with the Office for Protection of Economic Competition; we are also trying to identify the factors that influence the likelihoods that the petitioning candidates will be obstructive in nature and then compare the model's results describing non-obstructive and obstructive behaviour.

In the context of our approach we simplify the definition of obstructive behaviour regarding the petitions that have subsequently been withdrawn or for the petitions, whose deposits have not been paid. Thus two models are created: one for petitions, whose main purpose is not to create obstruction, and one for the so-called obstructive behaviour. 
Based on the above aims of the article, we define, for both models, the following hypotheses:

H1: The greater the volume of orders, the greater the odds ratio that the tenderer will file a petition for investigation of the contract with the Office for Protection of Economic Competition.

H2: Using the criterion of economic advantage implies that there is a higher odds ratio that the tenderer will file a petition for investigation of the contract with the Office for Protection of Economic Competition.

H3: The more the selection process is closed, the greater the odds ratio that a petition will be filed with the Office for Protection of Economic Competition.

H4: In the case of the central authorities, there is a greater odds ratio that a petition will be filed to investigate the contract with the Office for Protection of Economic Competition.

\section{Data a Methodology}

In the empirical analysis, data on public procurement were used, with the announcement and the awarding being published in the Bulletin of Public Contracts between 2007 and 2014 (i.e. including cancelled contracts). There are a total of 99,204 contracts. These data were combined with information about the administrative decisions from the Office for Protection of Economic Competition issued during the period January 2011 to March 2015 and published in the ECR Competition Office amounting to 1,965 decisions.

Because this data contains more decisions on the same contracts and some decisions related to contracts which were not published in the Bulletin of Public Contracts (for example public minor contracts or cases where the contracting body failed to publish information regarding the contract in the Bulletin), in total 917 tracked contracts were referred to in the Bulletin of Public Contracts of which the Office for Protection of Economic Competition handled with administrative proceedings. Of this total, 772 proceedings were initiated by petition and in the 295 of the cases the Office found that there were violations of the law by the contracting body.

The data were then, with respect to the hypothesis, analysed through an econometric model. Given the nature of the response variables (see below) logistic regression (logit) was used utilizing the logistic function for estimating parameters.

\subsection{Dependent variables}

The model aims to seek a partial explanation of the likelihood that the tenderer files a petition for an investigation of the contract with the Office for Protection of Competition. For this reason, a relevant dummy variable is created that takes the value 1 in the event of the filing of a petition, and in the absence of a filing of a petition a value of 0 is obtained.

We then focus on the so-called special cases such as obstructive petitions filed with the Office for Protection of Competition for which the model needs to consider petitions where the deposits have not been paid, or ones which have been subsequently withdrawn. Data analysis for the period shows that a withdrawal of the petition occurred in $27.3 \%$ of cases and the deposit was not paid in $10.8 \%$ of cases initiated on the basis of a petition. 
It should be noted that an amendment to Act on Public Contracts from March 2015 has tightened the rules, which in the case of the withdrawal means that $20 \%$ of the deposit is forfeited, and upon failure to pay the deposit, the administrative proceedings will be terminated even earlier. We are creating a dummy variable that in the event of an obstructive proposal has a value of 1 , and in other cases 0 .

\subsection{Explanatory variables}

\section{Estimated value of Public Contract}

As an explanatory variable describing the size of public contracts includes the estimated value of the contract which is denominated in CZK without VAT. This value is the contracting body's responsibility to determine prior to the commencement of a public contract. This value also determines whether the contracting authority is obliged to act according to the law or not.

An estimated value (average) of CZK 26,260,245.95 and a median value of CZK $5,383.470$ was obtained from the data. The data was eliminated for contracts with a value of less than CZK 10,000, as these were considered to be data-entry errors dealing with the value or unit prices.

\section{Type of Contracting Body}

For specifying the type of authority there was taken breakdown from the Bulletin of Public Contracts: Regional or Local Body, State or Federal Office or Agency, Public Institutions, Regional or Local Office or Agency, Ministry or any other national or federal authority, including their components.

\section{OtherType of Contract and Type of Award Procedure}

When specifying the type of public contractor or the type of procurement procedure, a basic classification according to the law was used. The data analysed represented 30,617 public contracts for goods, 30,062 contracts for services and 38,525 contracts for construction work.

\section{Other explanatory variables}

- Whether there was use of evaluation according to the lowest bid price $-68.3 \%$ of the analysed contracts

- Whether there was use of electronic auctions $-2.4 \%$

- Contract is financed from the EU subsidies - 35.5\%

- Contract is divided into parts $-9.2 \%$

- Contract is awarded for other contracting authorities (centrally awarded) $-2.5 \%$

\section{Results and Discussion}

In the following section we present the basic parameters of the performed econometric models for the general filing of petitions, and the special case of obstructive behaviour and the consequent results of hypothesis tests.

The results and comparison of the two models are presented in the following Table 2:

In the context of the interpretation of the model results, we can conclude that the model confirmed all the hypotheses. Hypothesis $\mathbf{H 1}$ was confirmed, which argues that the larger amount of the contract, the greater the odds ratio that the applicant will file a petition to investigate the contract to the competition regulator. The identified empirical 
examination results are consistent with theoretical assumptions indicated in this study. The actors who appeal to the competition regulator, behave as rational economic agents, who expect that their petition will maximize their own benefit.

Table 2 | Econometric Models (logit) for General Filing of Petitions, and Special Case of Obstructive Behaviour

\begin{tabular}{|c|c|c|c|c|c|c|}
\hline \multirow{2}{*}{$\begin{array}{c}\begin{array}{c}\text { Model - Explained } \\
\text { variables }\end{array} \\
\text { Explanatory variables }\end{array}$} & \multicolumn{3}{|c|}{ Filed Petitions } & \multicolumn{3}{|c|}{ Filed Obstructive Petitions } \\
\hline & Coefficient & $p$-value & $\begin{array}{l}\text { Marginal } \\
\text { effects }\end{array}$ & Coefficient & $p$-value & $\begin{array}{l}\text { Marginal } \\
\text { effects }\end{array}$ \\
\hline Constant & -4.77271 & $<0.00001$ & - & -6.25428 & $<0.00001$ & - \\
\hline Assigned to other & 0.898211 & $<0.00001$ & -0.000959 & 0.877235 & 0.00254 & 0.003042 \\
\hline Ratings by price & -0.222064 & 0.00546 & $4.87013 e-013$ & Not significant & - & - \\
\hline $\begin{array}{l}\text { Estimated value } \\
\text { of the public contract }\end{array}$ & $1.17821 \mathrm{e}-010$ & 0.00013 & 0.001377 & $1.11734 \mathrm{e}-010$ & 0.00212 & $2.47981 e-013$ \\
\hline Funded from grants & 0.317598 & 0.00008 & -0.002869 & 0.469504 & 0.00017 & 0.001124 \\
\hline $\begin{array}{l}\text { Contracting body - } \\
\text { a public institution }\end{array}$ & -0.887984 & $<0.00001$ & 0.003922 & -0.816381 & 0.00029 & 0.001444 \\
\hline Contracts for Service & 0.789358 & $<0.00001$ & 0.001130 & 0.670085 & 0.00017 & 0.001730 \\
\hline $\begin{array}{l}\text { Contracts for } \\
\text { Construction }\end{array}$ & 0.265573 & 0.01464 & 0.003058 & 0.594695 & 0.00053 & 0.001422 \\
\hline Restricted procedure & 0.56566 & 0.00001 & -0.006248 & 0.898385 & $<0.00001$ & 0.003100 \\
\hline $\begin{array}{l}\text { Negotiated procedure } \\
\text { without publication }\end{array}$ & -3.1947 & $<0.00001$ & -0.003406 & Not significant & - & - \\
\hline $\begin{array}{l}\text { Negotiated procedure } \\
\text { with publication }\end{array}$ & -1.36465 & $<0.00001$ & -0.004481 & -0.852092 & 0.01258 & 0.001353 \\
\hline $\begin{array}{l}\text { Simplified below } \\
\text { the threshold } \\
\text { procedure }\end{array}$ & -1.52238 & $<0.00001$ & -0.003207 & -1.47944 & $<0.00001$ & 0.002328 \\
\hline $\begin{array}{l}\text { Other types } \\
\text { of Procedures (not } \\
\text { including open } \\
\text { procedures) }\end{array}$ & -1.43168 & 0.01376 & -0.000959 & Not significant & - & - \\
\hline \multicolumn{7}{|c|}{ Overall characteristics of the model } \\
\hline McFadden $R^{2}$ & \multicolumn{3}{|c|}{0.073307} & \multicolumn{3}{|c|}{0.044907} \\
\hline Adjusted $R^{2}$ & \multicolumn{3}{|c|}{0.069967} & \multicolumn{3}{|c|}{0.039528} \\
\hline $\begin{array}{l}\text { Number of cases } \\
\text { correctly predicted }\end{array}$ & \multicolumn{3}{|c|}{$85,473(99.2 \%)$} & \multicolumn{3}{|c|}{$89,058(99.7 \%)$} \\
\hline Likelihood radio test: & \multicolumn{3}{|c|}{$X^{2}(12): 570.631[0.0000]$} & \multicolumn{3}{|c|}{$X^{2}(9): 166.983[0.0000]$} \\
\hline
\end{tabular}

Source: Authors

The results of the analysis confirm that the petitioning agents choose a strategy which takes into account both the size of the public contracts (estimated value) and the likelihood that they will be successful in their appeal. In his rational decision-making as to whether or not to submit a proposal to the competition regulator, the decision-making process of the petitioning tenderer is subject to the probability of success of the petition and to the size of the public 
contract. It means that a higher estimated value of a contract increases the likelihood that the tenderer will file a petition to initiate proceedings to review the actions of the contracting body before the Office for Protection of Competition, both in the case of obstructive petitions and non-obstructive petitions.

H2 hypothesis which maintains that the use of the economically advantageous tender criteria implies a greater odds ratio that the candidate will file a petition to investigate the contract to the Office for Protection of Competition, was also confirmed. The empirical analysis confirms that the use of the economic advantage criterion increases the likelihood that the tenderer will file a petition to the Office for Protection of Competition. Also, this conclusion is consistent with the conceptual and theoretical frameworks. The regulations within the Act on Public Contracts provides that it is necessary to establish how the subcriteria will be weighted when utilizing the criterion of economically advantageous tender. This fact is used by appellant applicants in their filing to the competition regulator. There may be different states. The choice of criteria and their weights can be for example that the contracting body deliberately establishes criteria in such a way that favours one of the contestants. This is, of course, illegal behaviour. On the other hand, some candidates may subjectively feel that the sub-criteria and weights are set up in a discriminatory manner to favour certain tenderers, although in reality this is not the intention of the contracting body. We can clearly see that there a new theoretical problem appears, which will be a challenge for further research. The question is this: what will the strategy of the contracting body be when choosing evaluation criteria and what will the impact of this strategy be with regard to the behaviour of the tenderers?

Hypothesis H3, regarding the situation when the award procedure is more closed, the greater the odds ratio that there will be more petitions filed to investigate the contract at the Office for Protection of Competition, has also been confirmed. The regulations of the public tender permit the use of various open (various transparent) types of award procedures. When the procedure is more open, a greater number or tenderers can participate. If the contracting body chooses the form of a closed tender, it is reasonable to expect that this factor will increase the likelihood of petitions being filed by the participants.

They may in fact perceive a competition which is more closed as a factor that discriminates. Additionally, regarding cases of actors who behave in an obstructive manner, they take a more closed competition as an advantageous opportunity to frustrate the public contract. This is confirmed by the results of empirical analysis: the use of more closed method of tender (restricted procedure) increases the likelihood that the tenderer will file a petition with the Office for the Protection of Competition. An exception to this case deals with the most closed type of procedure - the negotiated procedure without publication, where this is less likely on the grounds that such proceedings often involve only one tenderer.

The data also confirmed Hypothesis $\mathbf{H 4}$ which maintains that when the central authorities are the contracting bodies, there is a greater odds ratio that a petition will be filed to investigate the public contracts with Office for the Protection of Competition. The primary objective of the verification of this hypothesis was to investigate whether or not this hypothesis was valid, and if verified to utilize further socio-economic research project to find out what factors cause it. We believe that when dealing with the central authorities there is a lower rate of accountability and a higher likelihood that a petition will be filed regarding the public contract with the Office for Protection of Competition. Another factor may also be the issue of the politicization of the public (state) administration, when the interests 
of political parties which control the given body (e.g. The Ministry) within the public administration may enter the decision-making processes during the awarding of public contracts. This situation may lead to the unsuccessful bidders perceiving the behaviour of the contracting body as being unfair.

On the local level, there is probably a lower degree of politicization within the government. This can be inferred from the fact that people primarily vote for individual people rather than for a political party. Another factor may be the different level of transparency inside the environment of the central government compared to the local government. The environment at the municipal level seems to be more transparent. The people preparing the tender documents (and any potential "networking") are in the public domain, and therefore the contracting bodies on the local government level are much more limited in their possibilities to partake in collusion unlike anonymous ministerial officials. It would be necessary to investigate these conclusions (hypotheses) empirically in further research. It might help to clarify the detailed information gathered as to why there is a higher likelihood that a petition to investigate the public contracts issued by the central authorities will be filed with Office for the Protection of Competition.

Among other interesting findings, we can note that contracts financed from European subsidies have a greater likelihood of obstructive conduct. It is also interesting to learn that the contracts for services as well as a for construction projects also had a greater likelihood that tenderers would file a petition to initiate proceedings before the Office for Protection of Competition, which might be explained by the strong competition in the sector and it is also likely related to a more aggressive form of negotiations from these economic operators. We also intend to investigate this issue further in future examinations.

In conclusion we would like to state that even though at first glance, the results of both models seem similar, we can identify some interesting differences. For example, when looking at obstructive submissions, the evaluation criterion which the contracting body utilizes does not have a statistically significant effect on the odds ratio that a petition will be filed with the competition authorities. This is consistent with the theoretical basis that where obstructively behaving candidates use unfair methods (deceit, falsehood), regardless of what evaluation criteria were used. On the other hand, from the model it is clear that the use of the lowest price criteria does lower the odds ratio of non-obstructive petitions. It also is consistent with the theoretical premise. Non-obstructively behaving tenderers may be inwardly convinced that the sub-criteria as well as their weights have been set against them in a discriminatory manner and that the public tender did not respect the regulations established with respect to public contracts. When a single-criterion evaluation is utilized, such a situation does not arise. This explains why the use of a single-criterion evaluation reduces the likelihood that non-obstructive tenderers will file a petition. We also found that funding from the EU subsidies results in an increase of obstructive petitions. This conclusion is also to be taken up for further (interdisciplinary) research.

\section{Conclusion}

This article is another contribution to the current state of understanding in the field of postcontractual behaviour in public procurement and clarifies the role of regulator of the public contract. The main contribution of the paper is to identify selected characteristics of public contracts that affect the likelihood that the applicant will file a petition to initiate 
proceedings regarding a breach of the law with the Office for the Protection of Competition. These characteristics include: the size of public contracts (above its expected value), the choice of evaluation criteria, openness of the tender as well as the kind of contracting body. Econometric analysis shows that the petitioning tenderers act as a rationally behaving agents. In making their decisions regarding whether or not to submit a proposal to the competition regulator's office, their decision is influenced by the probability of the success of the petition, and by the size of public procurement.

\section{References}

Bajari, P., Tadelis,S. (2001). Incentives versus Transaction Costs: A Theory of Procurement Contracts. Rand Journal of Economics, 32(3), 387-407, http://dx.doi.org/10.2307/2696361

Bardach, E., (2000). Practical Guide for Public Policy Analysis. The Eightfold Path to More Effective Problem Solving. New York: Chatham House Publisher.

Brown, T. L., Potoski, M. (2003). Transaction Costs and Institutional Explanations for Government Service Production Decisions. Journal of Public Administration Research and Theory, 13(4), 441-468, http://dx.doi.org/10.1093/jopart/mug030

Burguet, R., Che, Y. K. (2004). Competitive Procurement with Corruption. Rand Journal of Economics, 35(1), 50-68, http://dx.doi.org/10.2307/1593729

Coase, R. H. (1937). The Nature of Firm. Economica (new series), 4(16), 386-405, http://dx.doi. org/10.2307/2626876

Domberger, S., Rimmer, S. (1994). Competitive Tendering and Contracting in the Public Sector: A Survey. International Journal of the Economics of Business, 1(3), 439-453, http://dx.doi. org/10.1080/758536232

EC (2014). Public Procurement Indicators 2012. Brussels: European Commission.

Hart, O., Shleifer, A., Vishny, R. W. (1997). The Proper Scope of Government: Theory and an Application to Prisons. The Quarterly Journal of Economics, 112(4), 1127-1161, http://dx.doi.org/10.1162/003355300555448

Horňáková, M., Špaček, D. (2013). Financial Management in Practice of Czech Regions Background Points, Experiences and Issues. In Špalková, D., Matějová, L. Proceedings of the 17th International Conference Current Trends in Public Sector Research. Brno: Masaryk University, Faculty of Economics and Administration, 237-245.

limi, A. (2006). Auction Reforms for Effective Official Development Assistance. Review of Industrial Organization, 28(2), 109 - 128, http://dx.doi.org/10.1007/s11151-006-0012-x

Jurčík, R. (2007). The Economic Impact of the EC Procurement Policy. Agricultural EconomicsZemědělská ekonomika, 2007(7), 333-337.

Jurčík,R. (2012). Projednání ekonomických a právních dopadů novelizací velké transparentní novely účinné od 1. 4. 2012 a návrhů nových zadávacích směrnic v Evropské unii. (Discussion of the Economic and Legal Implications of the Big Transparent Amendment Effective from 1 4th 2012, and Proposals for New Directives on Public Procurement in the European Union.) Ekonomický časopis/Journal of Economics, 60(7), 766-768.

Meričková, B., Nemec, J. (2007). Contracting-out Local Public Services - Situation and Trends in Slovakia and the Czech Republic. In: Nemec, J., ed., Lessons and Recommendations for Improvement: Central and Eastern European Public Administration and Public Policy. Bratislava: NISPAcee.

Mikušová - Meričková, B., Nemec, J. (2013). Contract Management and Its Impact on Contracting Public Services: Slovak Republic. Ekonomický časopis/Journal of Economics, 61(7), 690-699. 
Milne, R., McGee, M. (1992). Compulsory Competitive Tendering in the NHS. A New Look at Some Old Estimates. Fiscal Studies, 13(3), 96-111, http://dx.doi. org/10.1111/j.1475-5890.1992.tb00185.x

Nemec, J., Mikušová Meričková, B. and Grega, M. (2014). Contracting, Outsourcing, Procurement: Selected Factors Limiting their Success in the CEE Region. XVIII IRSPM Conference. April 9-11. Carleton University. Ottawa, Canada.

Nemec, J., Šumpíková, M., Klazar, S. et al. (2015). Efficiency versus Economy in Public Procurement. In Löster T., Pavelka T. Conference Proceedings: The $8^{\text {th }}$ International Days of Statistics and Economics. Prague: Melandrium.

Neumann, J., Morgenstern, O. (1944). Theory and Games and Economic Behavior. Princeton University Press, 1944.

Nikolovová, P., Palguta, J., Pertold, F., Vozár, M. (2012). Veřejné zakázky v ČR. Co říkají data o chování zadavatelů? (Public Procurement in Czech Republic: What Do Data Show about Contracting Authorities?) Studie 5. Prague: Národohospodářský ústav AV ČR, CERGE.

Ochrana, F., Maaytová, A. (2012). Východiska pro utváření transparentního a nekorupčního systému zadávání veřejných zakázek. (The Basis for the Formation of a Transparent and Non-Corruption Public Procurement System.) Ekonomický časopis/Journal of Economics, $60(7), 732-745$.

Patton, C. V., Sawicki, D. S. (1993). Basic Methods for Policy Analysis and Planning. Second Edition. Upper Saddle River - NJ: Prentice Hall.

Pavel, J. (2010). Analýza vlivu míry konkurence na cenu rozsáhlých staveb dopravní infrastruktury. (The Analysis of Influence Competition Factor on the Price of Large Transport Infrastructure.) Politická ekonomie, 58(3), 343-356, http://dx.doi.org/10.18267/j.polek.734

Pavel, J., Sičáková-Beblavá, E. (2008). Transparentnost' trhu verejného obstarávania.

(Transparency in the Public Procurement Process) Ekonomický časopis/Journal of Economics, 56(2), 168-181.

Pavel, J., Sičáková-Beblavá, E. (2012). Postkontraktační chování veřejných zadavatelů na Slovensku. (The Postcontractual Behaviour of Public Procurement Authorities in Slovak Republic.) Politická ekonomie, 60(5), 635-648, http://dx.doi.org/10.18267/j.polek.867

Schmidt, M. (2014). Pokuty za správní delikty ve veřejných zakázkách: ekonometrický model. (Penalties for Administrative Offences in Public Procurement: An Econometric Model) Acta Oeconomica Pragensia, 2014(6), 35-50, http://dx.doi.org/10.18267/j.aop.457

Svidroňová, M., Vaceková, G. (2012). Current State of Self-Financing of Private non Profit Organizations in the Conditions of the Slovak Republic. Technological and Economic Development Economy, 18(3), 438-451, http://dx.doi.org/10.3846/20294913.2012.702695

Strand, I., Ramada, P., Canton, E. et al. (2011). Public Procurement in Europe. Cost and Effectiveness. A Study on Procurement Regulation. Prepared for the European Commission, March 2011, Brussels.

Williamson, O. (1971). The Vertical Integration of Production: Market Failure Considerations. American Economic Review, 61(2), 112-123. Available at: http://www.jstor.org/ stable/1816983?seq=1\#page_scan_tab_contents

Williamson, O. (1981). The Economics of Organization: The Transaction Cost Approach. The Americn Journal of Sociology, 87(3), 548-577, http://dx.doi.org/10.1086/227496

Věstník veřejných zakázek (Bulletin of Public Contracts) (www.vestnikverejnychzakazek.cz). Act No. 137/2006 on Public Contracts, as amended. 